\title{
Oxidative Stress Investigation in Anemia
}

\author{
Derya Asci \\ Manisa Celal Bayar University, Faculty of Medicine, \\ Department of Physiology, Manisa, Turkey \\ Nuran Ekerbicer (Corresponding author) \\ Manisa Celal Bayar University, Faculty of Medicine, \\ Department of Physiology, Manisa, Turkey \\ E-mail: nuranaladag@hotmail.com, nuran.ekerbicer@cbu.edu.tr \\ Yesim Guvenc Demiragci \\ Manisa Celal Bayar University, Faculty of Medicine, \\ Department of Biochemistry, Manisa, Turkey \\ Raziye Yilmaz \\ Manisa Celal Bayar University, Faculty of Medicine, \\ Department of Biochemistry, Manisa, Turkey
}

\begin{abstract}
Introduction: Increased membrane rigidity, decreased deformability and hemolysis in erythrocytes are the result of oxidative damage. Our study included patients diagnosed with anemia and a control group of healthy individuals and in these groups, it was aimed to measure the level of Nitric Oxide (NO), which is an indicator of oxidative damage, and to determine the superoxide dismutase enzyme (SOD) activity, which are the most important components of the antioxidant system.
\end{abstract}

Material and Method: Ethics Committee approval was obtained for the study and patients who were diagnosed with iron deficiency anemia, $\mathrm{B}_{12}$ deficiency anemia, Talassemia minor at the hematology polyclinic of the Manisa Celal Bayar University Medical Faculty Hafsa Sultan Hospital were included in the study. Nitrite / nitrate levels were measured spectrophotometrically, SOD enzyme activity was measured by ELISA method.

Results: The difference between the study groups in terms of SOD values was not statistically significant. When nitric oxide results are compared; Thalassemia minor group values were significantly higher than control group $(\mathrm{p}<0.05)$.

Conclusions: Increased levels of NO, especially in the thalassemia patient group, it is thought to be the cause of hemolytic anemia as a result of oxidative stress and lipid peroxidation in this patient group.

Supporting Institutions: Manisa Celal Bayar University Scientific Researches Unit (2015-092).

Keywords: Anemia, Antioxidant System, Nitric Oxide, Superoxide Dismutase.

DOI: $10.7176 / \mathrm{JHMN} / 75-03$

\section{Anemilerde Oksidatif Stresin Değerlendirilmesi}

Özet

Giriş: Eritrositlerde artan membran rijiditesi, azalan deformabilite ve hemoliz oksidatif hasarın bir sonucudur. Çalışmamıza anemi tanısı konan hastalar ve sağlıklı bireylerin oluşturduğu kontrol grubu dâhil edilmiştir ve bu gruplarda, oksidatif hasarın bir göstergesi olan Nitrik Oksit (NO) seviyesinin ölçülmesi ve antioksidan sistemin en önemli bileşenleri olan süperoksit dismutaz enzim (SOD) aktivitesinin belirlenmesi amaçlanmıştır.

Gereç ve Yöntem: Çalışma için gerekli Etik Kurul onayı alınmış olup, Manisa Celal Bayar Üniversitesi Tıp Fakültesi Hafsa Sultan Hastanesi Dahiliye Hematoloji polikliniğinde demir eksikliği anemisi, $\mathrm{B}_{12}$ vitamin eksikliği anemisi, Talasemi minör tanısı alan hastalardan yararlanıldı. Nitrit/nitrat düzeyleri 
spektrofotometrik olarak, SOD enzim aktivitesi ELISA yöntemi ile ölçülmüştür.

Bulgular: Çalışma grupları arasında SOD değerleri açısından farkın istatistiksel olarak anlamlı olmadığı saptanmıştır. Nitrik oksit sonuçları karşılaştırıldığında; Talasemi minör grubunun değerleri kontrol grubuna göre anlamlı olarak yüksek bulunmuştur $(\mathrm{p}<0,05)$.

Sonuçlar: Özellikle talasemi hasta grubunda artan NO düzeyinin; bu hasta grubunda ortaya çıkan oksidatif stres ve lipid peroksidasyonunun bir sonucu olarak hemolitik anemi nedeni olduğu düşünülmektedir.

Destekleyen Kurumlar: Manisa Celal Bayar Ü. Bilimsel Araştırmalar Birimi (2015-092)

Anahtar Kelimeler: Anemiler, Antioksidan Sistem, Nitrik Oksit, Superoksit Dismutaz.

\section{GIRIŞ VE AMAÇ}

Kan hastalıkları günümüzde de önemini koruyan hastalıklar grubunda yer almaktadır. Kazanılmış yada ilaçlara bağlı hemolitik anemiler ile pernisiyöz anemi yanı sıra talasemi, orak hücreli anemi ve demir eksikliği anemileri toplumda önemli oranda görülen ve kronik kan hastalıklarını oluşturan temel nedenler arasında yer almaktadır.

Aneminin hemen daima bir hastalık olmayıp altta yatan bir hastalığın belirtisi olduğu unutulmamalıdır (Atamer 2004). Anemisi olan hastada klinik belirti ve bulgular aneminin derecesine, aneminin gelişme hızına, hastanın kalp, akciğer ve santral sinir sisteminin işlevlerinin durumuna, hastanın yaşına, anemiye neden olan altta yatan hastalığa bağlıdır (Atamer ve ark. 2003; Ali R.,2005). Anemili kişilerde iştahsızlık, dispeptik yakınmalar saptanmakla birlikte, bu semptomlar genellikle anemiyi oluşturan hastalığa bağlıdır.

Reaktif oksijen türevleri (ROT), oksijenin indirgenmesi tepkimeleri ile oluşmaktadır. ROT, enzim aktivitelerine ve diğer enzimatik olmayan maddelere bağlı olarak bir savunma sistemi tarafindan kontrol edilmektedir. ROT ve vücudun savunma sistemi arasındaki dengesizlik “oksidatif stres” olarak adlandırılmaktadır (Cheesman K.H.,1993; Reiter R.J., 1995; Kılınç K.,2002). Radikal oksijen türevi olan bileşikler olarak hidroksil, süperoksit, nitrik oksit, radikal olmayan oksijen türevi olan bileşikler olarak da hidrojen peroksit, singlet oksijen, ozon, hipoklorit sayılabilir (Meister 1994; Southorn 1988). Nitrik oksit (NO), gelişmiş canlılarda çok önemli biyolojik fonksiyonları yerine getirmek üzere üretilen nitrojen merkezli bir radikaldir (Kılınç K. 2002). Lipofilik özellikte olup, oksijensiz ortamda oldukça stabildir (Moncada ve ark. 1991). Düşük konsantrasyonlarda iken, ortamda oksijen varlığında dahi stabilitesini koruyabilir (Lancaster 1990; Marletta 1993). NO, endotel hücre disfonksiyonu ve buna bağlı ateroskleroz, hipertansiyon, şizofreni, bipolar bozukluk, otizm ve diabetes mellitus gibi bazı önemli hastalıklarda rol oynayabilmektedir (Yanık M. ve ark. 2003; Yanık M. ve ark. 2004).

ROT'nin oluşumunu ve bunların meydana getirdiği hasarı önlemek için birçok savunma mekanizmaları bulunmaktadır. Bu mekanizmalar "antioksidan savunma sistemleri" veya kısaca "antioksidanlar" olarak

bilinir. Süperoksit Dismütaz (SOD); süperoksit serbest radikalinin $\left(\mathrm{O}_{2}^{-}\right)$hidrojen peroksit $\left(\mathrm{H}_{2} \mathrm{O} 2\right)$ ve moleküler oksijene $\left(\mathrm{O}_{2}\right)$ dönüşümünü katalizleyen bir antioksidan enzimdir. SOD'un fizyolojik fonksiyonu, hücreleri süperoksit serbest radikali'nin $\left(\mathrm{O}_{2}^{-}\right)$lipid peroksidasyonu gibi zararlı etkilerine karşı korumaktır (Yanık M. ve ark 2003).

Eritrositlerde artan membran rijiditesi, azalan deformabilite ve hemoliz oksidatif hasarın bir sonucudur. Literatürde talasemi minor, $\mathrm{B}_{12}$ vitamini eksikliği ve demir eksikliği anemisinde; anemi ile oksidan/antioksidan sistem arasındaki ilişkiyi gösteren sınırlı sayıda çalışma mevcuttur. Çalışmamızda anemi tanısı konmuş hasta grubu ile sağlıklı bireylerden oluşturulan kontrol grubunda oksidatif hasar belirteci olan Nitrik oksit (NO) plazmada, antioksidan sistemin en önemli bileşenleri olan süperoksit dismutaz (SOD) enzimi ise eritrositlerde belirlenerek, aralarındaki ilişki araştırılmıştır. Özellikle talasemi hasta grubunda artan NO düzeyinin; bu hasta grubunda ortaya çıkan oksidatif stres ve lipid peroksidasyonunun bir sonucu olarak hemolitik anemiye neden olduğu düşünülmektedir.

\section{GEREÇ VE YÖNTEMLER}

\section{Denekler:}

Bu çalışmamız için gerekli Etik onay, Manisa Celal Bayar Üniversitesi Tıp Fakültesi Yerel Etik Kurulu 20478486/303 no'lu kararı ile alınmıştır. Projemiz MCBÜ Bilimsel Araştırma Projeleri Komisyonunun 2015-092 numaralı projesi olarak desteklenmiştir.

17 I P a g e

www.iiste.org 
Çalışmamız üniversitemizin Hafsa Sultan Hastanesi Hematoloji Polikliniğine anemi nedeniyle başvuran 3 ayrı grup kan örneğiyle ve kontrol grubuyla yapıldı.

Kontrol grubu $(\mathrm{n}=15)$,

Demir eksikliği anemisi grubu(n=15),

$\mathrm{B}_{12}$ vitamini eksikliği grubu(n=15),

Talasemi minor anemi grubu(n=15)

Çalışmamıza katılma kriterleri Manisa Celal Bayar Üniversitesi Tıp Fakültesi Hastanesi Dâhiliye Hematoloji polikliniğgine başvuran $\mathrm{B}_{12}$ eksikliği anemisi, Demir eksikliği anemisi ve Talasemi minor tanısı almış hastalar olarak oluşturuldu ve bu hastalar arasında 18 yaş üstü olup kendi rızası ile araştırmaya katılmayı kabul edenlerden "Bilgilendirilmiş Gönüllü Onam Formu” alınarak çalışmaya dahil edildi.

Tam kan sayımı ve periferik yayma

Eritrosit ile ilgili ölçümler ve diğer kan sayım ölçümleri Manisa Celal Bayar Üniversitesi Biyokimya Laboratuarında bulunan tam kan sayım cihazıyla yapıldı. Ayrıca çalışma kapsamında yer alan hastaların ve kontrol grubu gönüllülerinin bilgilendirilmiş gönüllü onam formunu imzalamasından sonra periferik yayma preparatları hazırlandı ve Fizyoloji ABD araştırma laboratuarında boyanıp, fotoğrafları çekildi.

\section{SOD (Süperoksit Dismutaz)}

SOD analizi, Superoxide Dismutase Assay Kit (Cayman Chemical Company. AnnArbor, USA) kullanılarak kolorimetrik olarak ölçülmüştür.

Kontrol ve hasta gruplarından EDTA' 11 tüplere venöz kan alındı. EDTA’ 1 tüpler 4000 devir/dk. hızda 10 dakika santrifüj edildi. Elde edilen plazma ependorf tüplere ayrilarak $-80^{\circ} \mathrm{C}$ 'lik derin dondurucuda analiz yapılacak güne kadar saklandı.

\section{Örneklerin hazirlanması}

Çalışma gününe kadar $-80^{\circ} \mathrm{C}$ saklanan plazmalar, dondurucudan çalışma gününden önceki gece çıkartıldı ve $2-8{ }^{0} \mathrm{C}$ dolapta bekletildi. Çalıșmanın yapılacağı gün dolaptan çıkarılıp, çalışma saatine kadar oda sıcaklığına gelmesi sağlandı. SOD aktivitesi bakılmadan önce örnek, plazma tamponu (Sample buffer) ile 1:5 oranında seyreltildi.

\section{Standartların Hazırlanması}

SOD stok çözeltisini elde etmek için $20 \mu \mathrm{l}$ SOD standardı $1.98 \mathrm{ml}$ numune tamponu (seyreltik) ile seyreltildi. Yedi adet temiz cam test tüpüne alınıp numaralandırıldı. Her tüpe SOD stoğu ve numune tamponu (seyreltik) eklendi. Prosedürün tamamlanması ardından her bir plate bir çalkalayıcıda oda sıcaklığında 30 dakika inkübe edildi. Bir ELISA okuyucu kullanılarak 450nm 'de absorbansı okundu.

\section{NO (Nitrik Oksit)}

Kontrol ve hasta gruplarından alınan lityum heparinli tam kan 4000 devir/dk. hızda 10 dakika santrifüj edildi. Elde edilen plazma ependorflara ayrılarak $-80^{\circ} \mathrm{C}$ 'lik derin dondurucuda analiz yapılacak güne kadar saklandi.

\section{Deneyin Prensibi:}

Vücutta endojen olarak üretilen nitrik oksitin doku ve vücut sıvılarındaki konsantrasyonu, pek çok çalışmada nitrit ve nitrat olarak ifade edilmiştir. Çünkü nitrik oksit, üretildiği bölgede saniyeler içinde okside olarak önce nitrite $\left(\mathrm{NO}_{2}^{-}\right)$daha sonra da nitrata $\left(\mathrm{NO}_{3}^{-}\right)$dönüşür. Nitrik Oksid üretiminin göstergesi olarak, stabil nitrik oksid metabolitleri olan Nitrit (NO -) ve Nitrat (NO -) ölçümü Griess reaksiyonu kullanılarak spektrofotometrik olarak yapıldı. Bununla beraber proteinden zengin homojenat yani serum, plazma gibi solüsyonlarda spesifik olmayan reaksiyonlar oluşabileceğinden, bu non spesifik reaksiyonların önüne geçebilmek adına plazmalar önce deproteinize edilip sonra konsantrasyonları ölçüldü. Yapılan son nitrit ölçümü total NO (nitrit+nitrat)'in göstergesi olarak kaydedildi.

\section{BULGULAR}

\section{Çalışma Gruplarının Kan Sayım Değerlerinin Karşılaştırılması}

Demir Eksikliği Anemisi, B 12 Eksikliği, Talasemi Minor'lü hastalar ve kontrol grubunun Tam Kan Sayım Parametreleri Tablo 1'de gösterilmiştir. 
Tablo 1. Tam Kan Sayım Parametreleri Ortalama ve Standart Sapmaları

\begin{tabular}{|c|c|c|c|c|c|c|c|c|}
\hline \multirow[b]{2}{*}{ Kan Değerleri } & \multicolumn{2}{|c|}{ Kontrol } & \multicolumn{2}{|c|}{ Demir Eksikliği } & \multicolumn{2}{|c|}{ 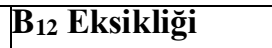 } & \multicolumn{2}{|l|}{ Talasemi } \\
\hline & $\begin{array}{l}\text { Ort } \\
\pm \text { Std }\end{array}$ & $\begin{array}{l}\text { Min- } \\
\text { mak }\end{array}$ & Ort \pm Std & $\begin{array}{l}\text { Min- } \\
\text { mak }\end{array}$ & Ort \pm Std & $\begin{array}{l}\text { Min- } \\
\text { mak }\end{array}$ & Ort \pm Std & $\begin{array}{l}\text { Min- } \\
\text { mak }\end{array}$ \\
\hline Hgb (g/dl) & $\begin{array}{l}14,02 \\
\pm 1,35\end{array}$ & $\begin{array}{l}12,4- \\
16,7\end{array}$ & $\begin{array}{l}9,50 * * * \\
\pm 1,6\end{array}$ & $\begin{array}{l}7,1- \\
12,9\end{array}$ & $\begin{array}{l}10,26^{* * * *} \\
\pm 2,87\end{array}$ & $5-13,8$ & $\begin{array}{l}10,20 * * * \\
\pm 2,57\end{array}$ & $\begin{array}{l}5,3- \\
15,7\end{array}$ \\
\hline HCT (\%) & $\begin{array}{l}41,97 \\
\pm 4,02\end{array}$ & $\begin{array}{l}36,5- \\
47,9\end{array}$ & $\begin{array}{l}29,45 * * * \\
\pm 4,82\end{array}$ & $\begin{array}{l}23- \\
40,1\end{array}$ & $\begin{array}{l}31,44 * * * \\
\pm 8,2\end{array}$ & $\begin{array}{l}15,2- \\
41\end{array}$ & $\begin{array}{l}32,25 * * * \\
\pm 6,75\end{array}$ & $21,6-46$ \\
\hline $\operatorname{MCV}(f 1)$ & $\begin{array}{l}85,66 \\
\pm 3,97\end{array}$ & $\begin{array}{l}78,1- \\
93\end{array}$ & $\begin{array}{l}77,64 \\
\pm 13,78\end{array}$ & $\begin{array}{l}52,7- \\
106,6\end{array}$ & $\begin{array}{l}87,01 \\
\pm 19,9\end{array}$ & $\begin{array}{l}50,2- \\
123,7\end{array}$ & $\begin{array}{l}70,30 * * \\
\pm 10,77\end{array}$ & $54-88,9$ \\
\hline $\begin{array}{l}\text { MCHC } \\
\text { (g/dl) }\end{array}$ & $\begin{array}{l}33,, 43 \\
\pm 0,59\end{array}$ & $\begin{array}{l}34,7- \\
34,8\end{array}$ & $\begin{array}{l}32,28 * * \\
\pm 1,003\end{array}$ & $\begin{array}{l}30,8- \\
34\end{array}$ & $\begin{array}{l}32,56 \\
\pm 1,58\end{array}$ & $\begin{array}{l}29,2- \\
34,4\end{array}$ & $\begin{array}{l}31,12 * * * \\
\pm 2,29\end{array}$ & $24,4-34$ \\
\hline RDW (\%) & $\begin{array}{l}13,54 \\
\pm 0.70\end{array}$ & $\begin{array}{l}12,5- \\
14,8\end{array}$ & $\begin{array}{l}17,57 * * * \\
\pm 2,96\end{array}$ & $\mid \begin{array}{l}13,7- \\
23,5\end{array}$ & $\begin{array}{l}17,00 * * \\
\pm 4,3\end{array}$ & $\begin{array}{l}13,2- \\
29\end{array}$ & $\begin{array}{l}17,61 * * * \\
\pm 4,01\end{array}$ & $\begin{array}{l}12,27- \\
28,6\end{array}$ \\
\hline
\end{tabular}

Hbg: Hemoglobin, HCT: Hematokrit, MCV: Ortalama eritrosit hacmi, MCHC: Ortalama eritrosit hemoglobin konsantrasyonu, RDW: Eritrosit dağılım genişliği

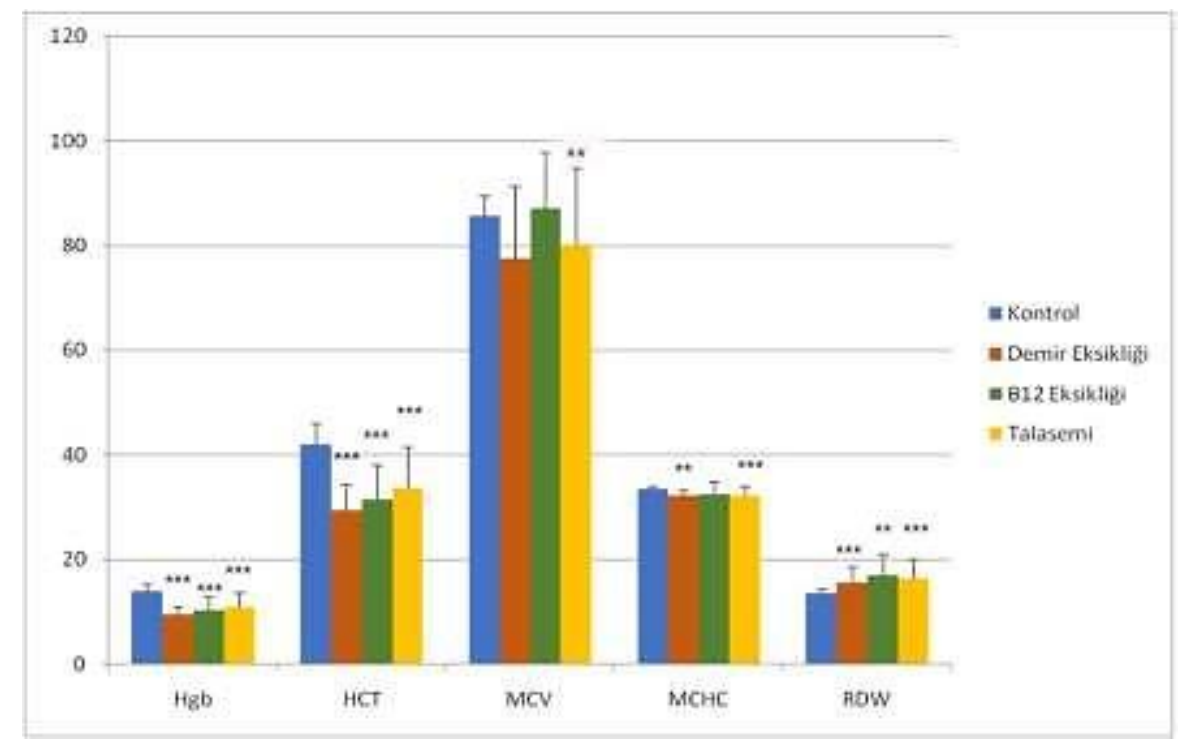

Şekil 1. Kontrol Grubu ve Hasta Örneklerinin Kan Sayım Değerlerinin Karşılaştırılması

$$
* \mathrm{p}<0,05, * * \mathrm{p}<0,01, * * * \mathrm{p}<0,001
$$

Çalışma gruplarının kan sayım değerlerinin karşılaştırılmasında; Hgb (Hemoglobin) ve Hct (Hematokrit) değerleri tüm anemi gruplarında kontrole göre anlamlı olarak düşük olarak saptandı $(\mathrm{p}<0.05)$.

MCV (Ortalama Eritrosit Volümü) değeri ise sadece Talasemi grubunda kontrole göre anlamlı olarak düşüktü $(\mathrm{p}<0.05)$.

MCHC (Ortalama Eritrosit Hemoglobin Konsantrasyonu) Talasemi ve Demir eksikliği gruplarında kontrole göre anlamlı olarak düşük olarak saptandı $(\mathrm{p}<0.05)$.

RDW (Eritrosit Dağılım Genişliği) değerleri ise; Demir eksikliği, Talasemi, $\mathrm{B}_{12}$ eksikliği gruplarında kontrole göre anlamlı olarak yüksek olarak saptandı $(\mathrm{p}<0.05)$ (Şekil 1). 


\section{Çalışma Gruplarının SOD (Süperoksit dismutaz) ve NO (Nitrik Oksit) Değerlerinin} Karşılaştırılması

Tablo 2. SOD ve NO sonuçlarının Ortalama ve Standart Sapmaları

\begin{tabular}{|c|c|c|c|c|c|c|c|c|}
\hline & \multicolumn{2}{|c|}{ Kontrol } & \multicolumn{2}{|c|}{ Demir Eksikliği } & \multicolumn{2}{|c|}{ B $_{12}$ Eksikliği } & \multicolumn{2}{|c|}{ Talasemi } \\
\hline & $\begin{array}{l}\text { Ort } \\
\pm \text { Std }\end{array}$ & Min-mak & $\begin{array}{l}\text { Ort } \\
\pm \text { Std }\end{array}$ & Min-mak & $\begin{array}{l}\text { Ort } \\
\pm \text { Std }\end{array}$ & Min-mak & $\begin{array}{l}\text { Ort } \\
\pm \text { Std }\end{array}$ & $\begin{array}{l}\text { Min- } \\
\text { mak }\end{array}$ \\
\hline SOD & $\begin{array}{l}2,39 \\
\pm 1,15\end{array}$ & $0,91-4,50$ & $\begin{array}{c}1,73 \\
\pm 0,52\end{array}$ & $1,07-2,91$ & $\begin{array}{l}2,68 \\
\pm 0,86\end{array}$ & $1,30-4,39$ & $\begin{array}{l}2,66 \\
\pm 1,03\end{array}$ & $\begin{array}{l}1,46- \\
5,29\end{array}$ \\
\hline NO & $\begin{array}{l}19,98 \\
\pm 2,65\end{array}$ & $16,1-25,4$ & $\begin{array}{l}19,32 \\
\pm 1,58\end{array}$ & $15,6-20,8$ & $\begin{array}{l}20,96 \\
\pm 4,82\end{array}$ & $16,1-36,4$ & $\begin{array}{l}23,60 \\
* * \\
\pm 2,25\end{array}$ & $\begin{array}{l}19,5- \\
30,4\end{array}$ \\
\hline
\end{tabular}

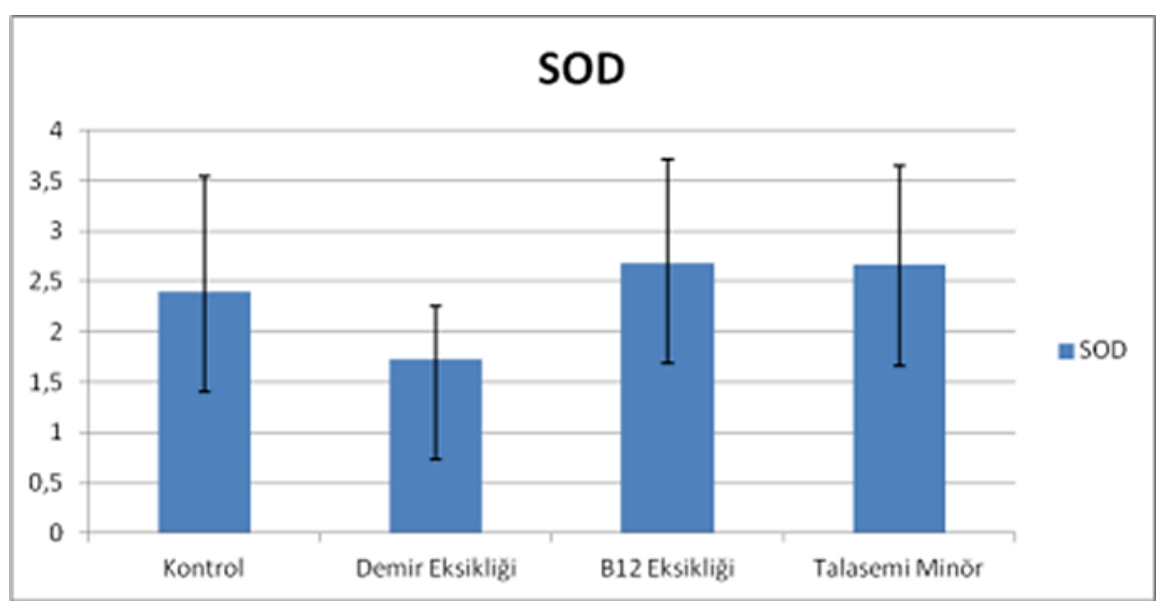

Şekil 2. Kontrol Grubu ve Hasta Gruplarının SOD (Süperoksit Dismutaz) Aktivitesi

$* \mathrm{p}<0,05, * * \mathrm{p}<0,01, * * * \mathrm{p}<0,001$

Çalışma grupları arasında SOD değerleri açısından farkın istatistiksel olarak anlamlı olmadı̆̆ saptanmıştır (Şekil 2).

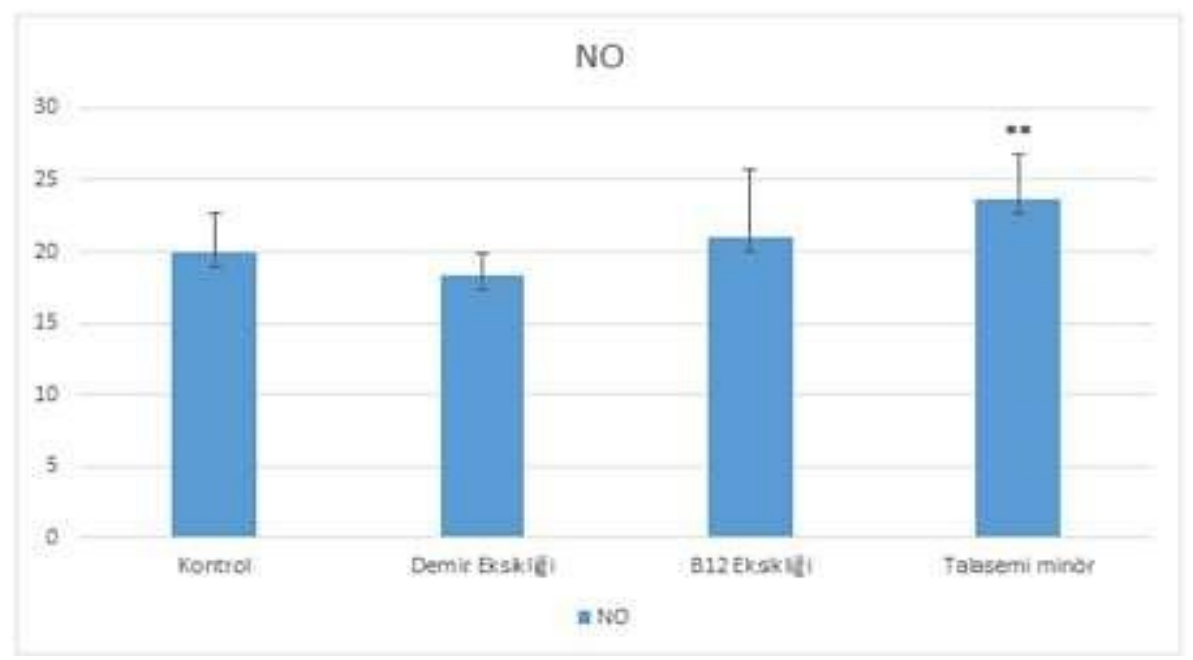

Şekil 3. Kontrol Grubu ve Hasta Gruplarının NO (Nitrik Oksit) Düzeyleri

$$
* \mathrm{p}<0,05, * * \mathrm{p}<0,01, * * * \mathrm{p}<0,001
$$


Nitrik oksit sonuçları karş̧laştırıldığında; Talasemi minor grubunun değerleri kontrol grubuna göre anlamlı olarak yüksek bulunmuştur ( $\mathrm{p}<0,05$ ) (Şekil 3) (Tablo 2).

\section{İstatistiksel Analiz}

$\mathrm{Bu}$ çalışmamızda veriler SPSS 15.0 bilgisayar istatistik paket programı aracılığıyla; tanımlayıcı istatistikler (ortalama, ortanca, standart sapma, minimum ve maksimum değerler) yapılmış ve gruplar arası karşılaştırmalar, Mann Whitney U testi kullanılarak değerlendirilmiştir.

\section{TARTIŞMA}

Anemi; hemoglobin miktarının cinsiyet ve yaşa göre dünya sağlık örgütü tarafindan kabul edilen kriterlerden düşük olmasıdır. Bu kriterler erişkin erkeklerde $13 \mathrm{~g} / \mathrm{dL}$, kadınlarda $12 \mathrm{~g} / \mathrm{dL}$ 'den düşük olanlarda kabul edilir (Altıparmak 2012). Tahminlere göre dünyada 1,5 milyar kişi anemiktir. Gelişmemiş ülkelerde \%36 olan anemi görülme sıklı̆ğ gelişmiş ülkelerde \%8'dir (Celkan ve ark. 2000).

Demir eksikliği anemisi, toplumumuzda her yaş gurubunda sıklıkla görülen bir sorundur. Demir eksikliği anemisinin dünyada en sık görülme sebepleri beslenme düzensizliği, kadınlarda jinekolojik kayıplar, postmenapozal kadın ve erkeklerde gastrointestinal sistemden kaynaklı kayıplar olup, dünya nüfusunun yaklaşı \%34'üne etki etmektedir. Demir eksikliği tanısı serum demiri, serum total demir bağlama kapasitesi(TDBK), çinko protoporfirin(ZnPP) düzeyi, transferrin satürasyon yüzdesi(TS), serbest eritrosit protoporfirin düzeyi ve serum ferritin düzeyi gibi yöntemlerle konulabilmektedir(McMullin ve ark. 2005).

Gülez ve ark. yaptıkları bir çalışmada, hemogram parametreleri içerisinde RDW ve MCV değerlerinin demir eksikliğinde tanı için önemli olduğunu bildirmişlerdir (Gülez ve ark. 1998). Benzer şekilde, J L Mahu ve ark. da en hassas ve spesifik parametrenin RDW, en az hassas ve spesifik parametrenin de MCHC olduğunu bildirmiş̧lerdir (Mahu ve ark. 1990). Bizim çalışmamızda kan sayımı sonuçlarımız değerlendirildiğinde; özellikle MCV değerinin Talasemi grubunda anlamlı olarak yüksek olduğu saptandı. MCHC değeri ise; hem Talasemi, hem de demir eksikliği anemisi gruplarında beklenildiği gibi, düşük bulunmuştur $(\mathrm{p}<0.05)$.

Yurdumuzda talasemi taşıyıcılığı da sık görülmektedir ve demir eksikliği anemisinin ayırıcı tanısında önemli bir yere sahiptir. Timur ve ark.'nın yaptığı bir çalışmada talasemi taşıyıcılığı ile demir eksikliği olan olguların ayırıcı tanısında RDW'nin duyarlılığ $\% 96$ olarak tespit edilmiştir (Timur ve ark. 1999). Bizim çalışmamızda da bunu destekler şekilde RDW değerleri özellikle kontrol grubuna göre tüm anemi gruplarında anlamlı derecede yüksek bulunmuştur; diğer kan parametrelerinden Hct ve Hgb değerleri ise kontrol grubuna göre, tahmin edileceği gibi, düşük saptanmıştır $(\mathrm{p}<0,05)$.

Talasemiler hemoglobin molekülünü oluşturan globin zincirlerinden bir veya daha fazlasının kusurlu sentezlenmesi sonucunda normal hemoglobin sentezinin azaldığ 1 veya tamamen durduğu heterojen otozomal resesif geçişli herediter hematolojik bir hastalıktır. Talasemili hastalarda; kronik anemiye bağlı doku hipoksisi, hemosiderozise bağlı endokrin bozukluklar (büyüme hormonu eksikliği, hipotiroidi, hipogonadizm), splenomegali, çinko ve folat eksikliği, yetersiz beslenme ve stres gibi faktörlerle ortaya çıkan büyüme geriliği tanımlanmıştır (Rachmilewitz ve Giardina 2011).

Hayatları boyunca çeşitli ekzojen ve endojen kaynaklı oksidanlara maruz kalan canlılar bunun sonucu olarak serbest radikaller üretirler (Halliwell 1994). Bu radikaller, kimyasal özelliklerinden dolayı oluştukları yerde çok hılı ve kolay bir şekilde hücredeki makro moleküllerle reaksiyona girebilmektedirler. Bu reaksiyonlarla birlikte çeşitli hasarlar oluşabilmektedir.

Serbest radikallerin oluşturduğu oksidatif stres ve oksidatif hasar; kanser, kardiyovasküler hastalıklar, diyabet, nörodejeneratif hastalıklar gibi birçok patofizyolojik sürecin erken evrelerinde önemlidir (Valko ve ark. 2005, Fibach ve Rachmilewitz 2008).

Oksidatif stresin hemolitik anemi, herediter sferositoz, hemoglobinopatiler (orak hücreli anemi ve talasemi) ve konjenital diseritropoetik anemi gibi hastalıklarda etkili olduğu bulunmuştur. Oksidatif stres bu hastalıkların birincil etiyolojisi değildir, ancak dolaşımdaki eritrositlerin yaşam sürelerini kısaltmasına ve kemik iliğindeki eritropoezin bozulmasina sebep olan oksidatif hasar, eritroid hücrelerdeki hemolizin oluşmasında kritik rol oynamaktadır. Yapılan bir çalışmada; demir eksikliği anemisi bulunan grupta tedavi öncesi total antioksidan kapasitenin kontrol grubu ile karşılaştırıldığında anlamlı olarak düşük olduğu bulunmuştur. Yine demir eksikliği anemisinde oksidan - antioksidan dengesinin bozulduğu, oksidatif stresin ortaya çıktığı sonucuna varılmıştır. Demir eksikliği anemisi olan grupta; eritrositlerin yüksek antioksidan etkinliğinin (SOD, GSH-Px gibi) bu hastalarda yetersiz olmasının iskelet kası, karaciğer, kalp ve kan hücrelerinde mitokondrial fonksiyon bozukluklarını yaratan süperoksit salınımına bağlanabileceği iddia edilmektedir (Fibach ve Rachmilewitz 2008).

Talasemi otozomal resesif geçiş gösteren heterozigot formda taşıyııllğa, homozigot formda hastalığa

21 P a g e 
neden olan bir kronik hemolitik anemidir. Globin zincirlerinin yapımındaki gerçekleşen anormallikler talasemi fenotiplerinde farklılıkların ortaya çıkmasına sebep olur. Talasemik eritrositlerin serbest radikallerle olusan oksidatif hasarı, demir toksisitesi ve lipid peroksidasyonu ile belirlenmiştir.

SOD, substrat olarak serbest oksijen radikallerini kullanan ve süperoksiti hidrojen perokside ve moleküler oksijene dönüşümünü katalize eden bir enzimatik antioksidandır. Oluşan reaksiyon "oksidatif strese karşı ilk savunma" olarak da adlandırılmaktadır. Aynı zamanda SOD, lipit peroksidasyonunu da inhibe etmektedir. SOD2 (MnSOD) enzimi, süperoksit anyonunun $\left(\mathrm{O}_{2}-\right)$, hidrojen perokside $\left(\mathrm{H}_{2} \mathrm{O}_{2}\right)$ ve oksijene dönüşümünü katalize ederler ve böylece bu radikallerin etkisini azaltır (Diplock 1998).

Meral ve arkadaşlarının beta talasemili hastalarda ve demir eksikliği tespit edilen çocuklarda yaptıkları çalışmada eritrosit antioksidan enzimlerinden SOD aktivitesi beta talasemi grubunda anlamlı yüksek bulunmuştur (Meral ve ark. 2000).

Asma Kassab-Chekir ve arkadaşlarının beta talasemili çocuklarda yaptıkları çalışmada; eritrosit SOD ve GSH-Px( Glutatyon peroksidaz) enzim aktiviteleri de kontrol grubuna göre yüksek bulunmuştur (KassabChekir ve ark. 2003). Chakraborty ve arkadaşlarının beta talasemili hastalarda yaptığı çalışmada eritrosit SOD, GSH-Px ve G6PD enzim aktivitelerinin talasemi taşıyıcılarına ve kontrol grubuna göre anlamlı artış gösterdiği saptanmıştır.

Metabolik sürecin önemli parçası olan hücreler sürekli serbest radikal ve reaktif oksijen türlerini meydana getirirler. Bu reaktif oksijen türleri ve serbest radikaller kompleks bir antioksidan sistem tarafindan nötr hale getirilir. Oksidatif stres, reaktif oksijen türleri veya serbest radikaller ile antioksidan sistem arasındaki dengesizliktir. $\mathrm{Bu}$ dengesizlik önemli hücre kompartımanlarında dönüşümü olmayan hasara sebep olabilir. Gerli ve arkadaşları talasemi major ve minorlü hastalarda SOD, CAT (Katalaz) ve GSHPx enzim aktivitelerini incelemişlerdir. Yaptıkları çalışmada talasemi majorlü olgularda enzim aktivitelerini normal eritrosit değerlerinde bulurken, talasemi minorlü olgularda enzim aktivitelerini yüksek bulmuşlardır. Bu bulgularla, Talasemi minorlü hastalarda sürekli oksidatif strese maruz kalmanın antioksidan enzim düzeylerini arttırdığını, talasemi majorlü hastalarda ise düzenli transfüzyondan dolayı sirkülasyonda normal eritrositlerin bulunduğu, bu sebeple enzim aktivitelerinde artış gözlenmediği düşüncesini ortaya atmışlardır (Gerli ve ark. 1980).

Vives, Miguel-Garcia ve arkadaşlarının beta talasemi, demir eksikliği anemisi ve beta talasemi taşıyıcılarında yapmış olduğu çalışmada MDA (Malondialdehit) yapımında ve SOD, GSH-Px enzim aktivitelerinde beta talasemi grubunda diğer iki gruba göre artış olduğu belirlenmiştir (Vives ve ark. 1995). Beta talasemide beta globin zincir yapımındaki dengesizlik sebebiyle artan alfa globin zincirleri, eritrositlerin zar yapılarını bozarak ve eritrosit öncül hücrelerinin erken yıkımını hızlandırarak eritrositlere zarar verirler. Ünal çalışmasında beta talasemi, G6PD ve demir eksikliği anemisi olan grupları karşılaştırmıştır. Sonuçta beta talasemi grubunun SOD enzim düzeyi kontrol grubuna göre farklı bulunmazken MDA düzeyi kontrol grubuna göre anlamlı yüksek bulmuştur (Ünal 1999). Corrons ve arkadaşları SOD aktivitesinin; talasemi grubunda demir eksikliği anemisi grubuna göre yüksek olduğunu belirtmişlerdir (Corrons ve ark. 1995).

Zaidi ve arkadaşları; zaman ya da doza bağımlı olarak, demir uygulamalarında eritrosit membranı $\mathrm{Ca}^{+2} \mathrm{Mg}^{+2} \mathrm{ATP}$ 'az aktivitesinin baskılandığını, bunun sonucunda da hasarın arttı̆̆ını bulmuşlardır (Zaidi ve ark. 1995). Galleno ve arkadaşları başka bir çalışmada $500 \mathrm{mg} / \mathrm{kg}$ demir dekstranın tek doz uygulanmasını takiben, 20 saat sonra karaciğer hemojenatlarında CAT, SOD ve GSH-Px seviyelerinin sirasıyla \% 25, \% 36 ve \% 32 oranlarında azalma gösterdiğini söylemektedirler(Galleno ve ark. 1994).

Bacon ve arkadaşları, akut demir uygulamasının lipid peroksidasyonunu arttırdığını bildirmişlerdir. Bununla beraber, düşük dozlarda $(30 \mathrm{mg} / \mathrm{kg})$ uyguladıkları demir dekstranın serbest radikal hasarını oluşturmadığını bulmuşlardır. Çalışmaların tamamını hayvanlarda yapılmıştır (Bacon ve Britton 1990). $\mathrm{Bu}$ konuyla ilgili hayvanlarda yapılmış çokça çalışma olmasına rağmen insanlarda ve de özellikle çocuklarda yapılmış az sayıda araştırma bulunmaktadır.

Tunç ve arkadaşları demir eksikliği anemisi olan 21 çocukta yaptıkları çalışmada hastalara oral iki değerli demir preparatı verip tedavi öncesinde ve sonrasında malondialdehid (MDA) düzeyi, süperoksid dismutaz (SOD), glutatyon peroksidaz (GSH-Px) ve katalaz aktivitelerini ölçmüş ve kontrol grubuyla karşılaştırmışlardır. Demir eksikliği anemi'li çocuklarda eritrosit lipid peroksidasyonun arttığını, bunun da anemi patogenezinde rol oynayabileceğini, uygun dozlarda kullanılan demir tedavisinin ilave bir oksidatif stres meydana getirmediği sonucuna varmışlardır (Tunç ve ark. 2001). Bizlerde çalışmamızda 3 farklı anemi grubunun SOD analizlerini gerçekleştirmiş olup, kontrol grubu ile karşılaştırıldığında SOD enzim reaktiviteleri arasında herhangi bir farklılık gözleyemedik. Bu durum, anemi gruplarına ilişkin kanların ilk tanı sırasında değil, daha sonrasında alınmaları ve belki de grupların tedavi almış olmaları ile ilişkili olabilir.

NO önemli immün fonksiyonları olan ve NOS tarafından L-arjininden üretilen bir serbest radikaldir. Arjinaz enzimi, ortak substrat olan L- arjinin için NOS ile yarışa girerek NO üretimini azaltabilir. NO oral

22 | $P$ a g e 
kavitenin patojenik mikroorganizmalara karşı nonspesifik koruyucu faktörlerden biridir (Avcı ve ark. 2009). NO vücutta vazodilatasyon, yara iyileşmesinin düzenlenmesi, enfeksiyona spesifik olmayan immün yanıt, konak savunması ve sitotoksisite vb. pek çok kritik role sahiptir. Çalışmamızda; karşılaştırma yaptığımız gruplar arasında; özellikle Talasemi grubunda NO düzeyinin anlamlı olarak yüksek olduğu saptanmıştır. Bu da bize; bu hasta grubunda oksidatif hasarın devam ettiğini göstermektedir.

Erkurt MA ve ark.yaptığı çalışmada megaloblastik anemide nitrik oksit seviyelerinin artış gösterdiğini vurgulamışlar ve yine çalışmalarında megaloblastik anemide nitrik oksit seviyelerindeki anormalliklerin vitamin $\mathrm{B}_{12}$ replasman tedavisi ile düzeltilebileceğini iddia etmişlerdir (Erkurt ve ark. 2009).

Anemi sürecinde artan oksidatif stres, lipid peroksidasyonunun artmasına, GSH-Px"in de içinde bulunduğu enzimatik antioksidan sistemin zayıflamasına (Kumerova ve ark. 1998) ve eritrositlerin prooksidanlara duyarlılığının artmasına neden olur (Melhom ve ark. 1971).

Aneminin oksidatif strese neden olduğu genel olarak bilinmekte, ancak bunun aneminin şiddet ve tipi ile ilişkisi konusunda detaylı bilgi bulunmamaktadır. Çalışmamızda kontrol grubu ile hasta grubu karşılaştırıldığında; hematolojik verilerde ve oksidatif stress belirleyicisi olarak reaktif nitrojen türlerinde (nitrit/nitrat olarak) anlamlı farklar gözlenmiş, ancak antioksidan sistem olarak SOD düzeyinde anlamlı fark gözlenmemiştir.

Sonuç: : Sonuçta; oksidatif stres araştırması için anemili olgularda yapılan çalışmaların tedavi almamış olgularda yapılmasının, özellikle ilk tanı konulmuş hasta grubunda yapılmasının antioksidan sistem sonuçları açısından daha sağlıklı olabileceği kanaatine varılmıştır.

\section{KAYNAKLAR}

Altıparmak MR, Hamuryudan V, Sonsuz A. (2012). Cerrahpaşa İç Hastalıkları. 2.Baskı. İstanbul Tip Kitabevi, p;187-320.

Ali R. (2005). Anemik hastaya yaklaşım ve anemilerin sınıflandırılması. In Dolar E. İç hastalıkları .1.B.İstanbul: Nobel Tip Kitapevleri; s.549- 53.

Atamer T. , Dinçol G, Pekcelen Y, Sargın D, Nalçacı M, Aktan M, Beşışık SK. (2003). Anemilerin sınıflandırılması ve anemik hastaya yaklaşım. Ístanbul Tip Fakültesi Temel ve Klinik Bilimler Ders Kitapları Klinik Hematoloji .1.B. İstanbul: Nobel Tıp Kitapevleri; s.33-45

Avc1 A, Tüzüner- Öncül M, Gökcan MK, Namuslu M, Öztürk A, Durak İ. (2009). Nitric oxide metabolism in cancerous and non-cancerous oral gingivomucosal tissue: Possible implications of nitric oxide in cancer process. J Oral Pathol Med; 38: 304-6.

Bacon Br, Britton SR. (1990). The pathology of hepatic iron overload: A free radical. Mediated process. Hepatology; 11(1):127-34.

Celkan T., Apak H., Özkan A., et al. (2000). Demir eksikliği anemisinde önlem ve tedavi. Türk Pediatri Arşivi; 35: 226-31.

Chakraborty d, Bhattacharyya M. (2001). Antioxidant defense status of red blood cells of patients with $\beta$-thalassemia and E $\beta$-thalassemia. Clinica Chimica Acta; 305:(123-129)

Cheesman, K.H:, Slater, T.F, (1993). An introduction to free radical biochemistry. British Medical Bulltin; 49(3): 481-493.

Corrons V.J.L, Garcia M.A, Pujades M.A. (1995). Increased susceptibility of microcytic red blood cells to in vitro oxidative stres. Eur J Haemotol;55:327-331.

Diplock AT., (1998). Healty lifestyles nutrition and physical activity: Antioxidant nutrients. ILSI Europe concise monograph series, Belgium; p 59.

Erkurt MA, Aydoğdu İ, Bayraktar N, Kuku İ, Kuku İ, Kaya E, (2009). Turk J Haematol. Dec 5; 26(4):197-200. 
Fibach E. , Rachmilewitz E. (2008).Curr Mol Med. Nov;8(7):609-19.

Galanello R, Origa R. (2010). Beta-thalassemia: Orphanet J Rare Dis.

Journal of Continuing Education Topics \& Issues; 21: 5-11.

Gerli GC, Beretta L, Bianchi M, Pellegatta A, Agostoni A. (1980). Erythrocyte superoxide dismutase, catalase and glutathione peroxidase activities in beta-thalassaemia (major and minor). Scand J Haematol; 25(1):87-92.

Gülez P, Kayserili E, Tosun A, Eryılmaz N. (1998). Demir Eksikliği Anemisinde Eritrosit Parametrelerinin Karşılaştırılması. Klinik Bilimler\&Doktor; 4(6):875-77.

Halliwell B, Gutteridge JMC, (1999). Free radicals in biology and medicine Oxford, Oxford University, p 84.

Kassab-Chekir A, Laradi S, Ferchichi S, Khelil A.H, Feki M, Amri F, Semli H, Bejaoui M, Miled A. (2003). Oxidant, antioxidant status and metabolic data in patients with beta-thalassemia. Clinica Chimica Acta; 338:(79-86).

Kılınç K, Kılınç A.,(2002). Oksijen toksisitesinin aracı molekülleri olarak oksijen radikalleri; Hacettepe Tip Dergisi; 33(2): 110-118.

Kumerova A., Lece A., Skesters A., Silova A., Petuhovs V. (1998). Anemia and antioxidant defence of the red blood cells. Mater med; pol 30,12-15

Lancaster J. (1990). Nitric oxide, principles and and actions. Copyright by Academic Press. Inc. California/USA.

Mahu JL, Leclercq C, Suquet JP. (1990). Usefullness of red cell distribution width in association with biological parameters in an epidemiological survey of iron deficiency in children. Int J Epidemol;19(3):646-54.

Marletta MA. (1993).Nitric oxide synthase structure and mechanism. J Biol Chem; 268: $123-5$.

McMullin BB, Chittock DR, Roscoe DL, Garcha H, Wang L, Miller CC. (2005). The antimicrobial effect of nitric oxide on the bacteria that cause nosocomial pneumonia in mechanically ventilated patients in the intensive care unit. Respir Care; 50: 1451-6.

Meister A. (1994). Glutathione Ascorbate and cellcycle regulation FEBBS letters; p: 1-4.

Melhorn DK, Gross S, Newman AJ, Filer LJ Jr, Fisher SE, Allen AC, Friedman GD. (1971). Iron-fortified formulas.Pediatrics. Dec; 48(6):999- 1003

Meral A, Tuncel P, Sürmen-Gür E, Özbek R, Öztürk E, Günay Ü. (2000). Lipid Peroxidation and Antioxidant Status in $\beta$-Thalassemia. Pediatric Hematology and Oncology;17: 687-693.

Moncada S, Palmer RMJ, Higs EA. (1991). Nitric oxide: Physiology, patophysiology, and pharmacology. J Pharmacol Review; 43: 109-37.

Rachmilewitz EA, Giardina PJ. (2011). How I treat thalassemia. Blood; 118: 3479-88.

Reiter, R.J. (1995). Oxidative process and antioxidative defence mechanism in the aging brain. The Faseb Journal. May; 9:526-533. 
Southorn P, Powis G. (1988). Free radical in medecine I. Chemical nature and bidogical reactions. J Mayo Clin Proc; 63: $381-8$.

Timur Ç, Ulukutlu L, Yüksel L, Ergeneman G, Yıldız İ. (1999). Demir eksikliği ile beta talasemi taşıyıcılarının ayırıcı tanısında RDW'nin değeri. Türk Pediatri Arşivi 1999;34 (1):39-42.

Tunç B, Özen H, Delibaş N, Sütçü R. (2001). Demir eksikliği anemili çocuklarda oral demir tedavisinin lipid peroksidasyonuna ve antioksidan enzim aktivitelerine etkisi. Türk Hematoloji Onkoloji Dergisi; 11(4):217-22.

Ünal B. B. (1999). Talasemi ve G6PD Enzim Eksikliğinde MDA Düzeyi. Uzmanlık Tezi, Çukurova Üniversitesi Tıp Fakültesi Biyokimya Anabilim Dalı, Adana.

Valko M, Rhodes Cj, Moncol J, Izakovic M, Manzur M, (2006). Free radicals, metals and antioxidants in oxidative stress-1nduced cancer. Chemico-Biological Interactions; 160 , $1-40$.

Vives Corrons JL, Miguel-Garcia A, Pujades MA, Miguel-Sosa A, Cambiazzo S, Linares M, Dibarrart MT, Calvo MA. (1995). Increased susceptibility of microcytic red blood cells to in vitro oxidative stres. Eur J Haematol; 55(5):327-31.

Yanik M, Vural H, Tutkun H, Zoroglu SS, Savas HA, Herken H, Kocyigit A, Keles H, Akyol O. (2004). The role of the arginine nitric oxide pathway in the pathogenesis of bipolar affective disorder. Eur Arch Psychiatry Clin Neurosci; 254: 43-47.

Yanik M, Vural H, Kocyigit A, Tutkun H, Zoroglu SS, Herken H, Savas HA, Koylu A, Akyol O. (2003). Is the arginine-nitric oxide pathway involved in the pathogenesis of schizophrenia? Neuropsychobiology; 47: 61-5. 